\title{
Seasonal and multi-annual patterns of colonisation and growth of sessile benthic fauna on artificial substrates in the brackish low-diversity system of the Baltic Sea
}

\author{
Adam Sokołowski $\mathbb{D} \cdot$ Marcelina Ziółkowska $\cdot$ Piotr Balazy $\cdot$ Piotr Kukliński · Irmina Plichta
}

Received: 7 June 2016/Revised: 12 September 2016/Accepted: 20 October 2016/Published online: 29 November 2016

(C) The Author(s) 2016. This article is published with open access at Springerlink.com

\begin{abstract}
Although benthic succession is well understood, the growth of assemblages does not follow the same progression across environmental variables and differs among coastal ecosystems. This study investigates the seasonal and multi-annual patterns of development of sessile invertebrate assemblages and the effects of environmental variables and substrate orientation (topsurface vs. undersurface) on this process. Perspex panels deployed on the seafloor horizontally were monitored seasonally from March 2008 to March 2010 (two locations) and yearly from March 2010 to April 2015 (one location) in the southern Baltic Sea. All faunal taxa occurred simultaneously in the first six months of immersion, but no clear sequence of colonising species was detected. Seasonal occupation of free space coincided with increased primary production in the water column and was driven by recruitment timing and intensity, and
\end{abstract}

Handling editor: Jonne Kotta

A. Sokołowski $(\varangle) \cdot$ M. Ziółkowska · I. Plichta Institute of Oceanography, University of Gdańsk, Al. Piłsudskiego 46, 81-378 Gdynia, Poland

e-mail: oceas@univ.gda.pl

P. Balazy · P. Kukliński

Institute of Oceanology, Polish Academy of Sciences, ul.

Powstanców Warszawy 55, 81-712 Sopot, Poland

P. Kukliński

Department of Life Sciences, Natural History Museum,

Cromwell Road, London SW7 5BD, UK the growth rates of recruits. More diverse and numerous assemblages developed on the panel undersurfaces presumably because of reduced physical disturbance. After 3 years of continuous immersion, the assemblage composition, but not its abundance, became stable and convergent towards the natural surrounding communities, which indicated the advanced successional stage. The rate of assemblage development was fast which can be attributed to weak interspecific competitive interactions and reduced feeding interferences among benthic fauna.

Keywords Sessile benthic macrofauna . Colonisation · Assemblage succession · Artificial hard substrate $\cdot$ Surface orientation $\cdot$ Baltic Sea $\cdot$ SCUBA

\section{Introduction}

Documenting patterns of sessile invertebrate community development in the marine environment is important for determining colonisation dynamics and for predicting recovery potential after disturbances. The successional sequence or pathways of invertebrates and the roles that abiotic and biotic factors play in mediating (e.g., facilitating, tolerating or inhibiting) the succession of species have only recently come to be understood (McClanahan, 1997). Ecological succession is defined as the gradual process of changes in species composition and abundance over time that possibly occurs through multiple stable points 
(Connell \& Slatyer, 1977; Petraitis \& Methratta, 2006). The process is continuous, sequential and directional, and it involves the colonisation and extinction of species, the growth of individual components and increments of diversity, biomass and structure which eventually leads to a stable finale-the climax community (Odum, 1969; Sousa, 1980; Pacheco et al., 2010). Community development on hard substrates depends on colonisation success, which is related to juvenile-adult interactions and initial conditions (Bullard et al., 2004), interspecific competitive interactions for available space and resources (Valdivia et al., 2005), predation (Osman et al., 1992) and grazing (Benedetti-Cecchi, 2000). Succession can also vary following fluctuations in environmental factors, including water temperature and its dynamics (waves, currents), substrate availability and primary production, all of which render succession highly seasonal in many temperate and subtropical systems (Pacheco et al., 2010; Speight \& Henderson, 2010).

Although there is a relatively good understanding of benthic succession across environmental variables and latitudes, ecological succession does not necessarily follow exactly the same linear progression to an end point, and it varies among coastal ecosystems (Petraitis \& Methratta, 2006). Divergent patterns of benthic succession can be expected, for example, in evolutionary young systems such as the Baltic Sea where numerous free ecological niches and low taxonomic richness can alter the successional sequences and rates. The Baltic is a young ecosystem that has been undergoing post-glacial successional changes continuously since the last glaciation 8000 years ago that are driven by strong physical and chemical environmental gradients (e.g., temperature, salinity and carbon) and ecological diversity (Jansson \& Jansson, 2002; Bonsdorff, 2006). Together with large freshwater inputs and high anthropogenic pressure (including eutrophication and pollution), this creates harsh ecological conditions locally in the Baltic. The resident biota comprises mainly euryhaline species that have extended their natural range from the North Atlantic, relicts from previous periods of sea history, and brackish and freshwater species with obviously opportunistic life strategies (sensu Levinton, 1970; Rumohr et al., 1996) and high potential for acclimatisation and/or adaptation. Benthic communities are considered immature (sensu Margalef, 1974) and species poor, and they are therefore vulnerable to bioinvasions (Leppäkoski et al., 2002). The low natural diversity of benthic assemblages reduces likely interspecific interactions and competition for resources (e.g., space and food), while locally specific environmental forces directly influence the physiological performance and growth of animals exerting a direct effect on the seasonality and course of successional development at smaller scales. The only full-year seasonal research by Dürr \& Wahl (2004) shows the synergistic negative effect of mussels and barnacles on fouling community structure in the subtidal Kiel Fjord in the western Baltic. Most field studies of natural succession in the Baltic Sea have been performed, however, on sedimentary habitats or on vertical experimental units (Chojnacki \& Ceronik, 1997; Dürr \& Wahl, 2004; Dziubińska \& Janas, 2007; Andersson et al., 2009; Dziubińska \& Szaniawska, 2010) and artificial marine constructions (Qvarfordt et al., 2006). To date, no investigations have been conducted on horizontal substrates that are installed directly on the sea floor and mimic natural hard bottoms in the coastal environment (Wahl et al., 2011). There is also little information on the succession of benthic fauna on substrates that are oriented on the bottom differently (with surfaces facing up and down) and on long-term (on the scale of years) development pattern of coastal benthic communities in this specific system. The only multiannual succession study that has been reported is that regarding the bridge in the Kalmar Sound, but the colonisation start points varied considerably because of the different submerging times of the concrete pillars (Qvarfordt et al., 2006)

This study investigates the seasonal and multiannual growth and succession development of the benthic macrofaunal community on artificial hard substrates in the coastal zone of the southern Baltic Sea (Gulf of Gdańsk). Three research hypotheses were tested as follows: $\mathrm{H}_{01}$ - the pattern of colonisation and succession of macrofaunal communities is highly seasonal and is attributed to the main environmental variables; $\mathrm{H}_{02}$ - the orientation of hard substrates affects the composition and succession rate of benthic fauna; $\mathrm{H}_{03}$ - the rate of macrofaunal community development in the southern Baltic Sea is fast relative to other temperate coastal systems. 


\section{Materials and methods}

\section{Experimental set-up}

Flat artificial Perspex panels (one-surface matt black) quadrate in shape and measuring $15 \mathrm{~cm} \times 15 \mathrm{~cm}$ each were deployed by SCUBA divers at a depth of $3.5 \mathrm{~m}$ at two coastal locations, both approximately $200 \mathrm{~m}$ from the shore and at a distance of approximately $14.1 \mathrm{~km}$ from each other: Mechelinki (MECH) and Gdynia (GDY) in the Gulf of Gdańsk (southern Baltic Sea; Fig. 1). The environmental and biological characteristics of the locations and the experimental panels used are described in detail in Sokołowski et al. (2017). Briefly, six panels were attached horizontally to PVC 1-cm spacers to form an experimental unit so that the matt surface of three panels was up (the socalled topsurface) and that of three panels was down (the so-called undersurface). Spacers maintained a $1-\mathrm{cm}$ vertical gap between the panels (Fig. 2) and 5 -cm horizontal space between the two neighbouring units. Five experimental units (comprised of six panels each) were attached in a horizontal position and parallel to each other and to a metal frame which was secured on the seafloor with stones and concrete sinkers following the model construction designed by Todd and Tuner (1986).

Deployment, sampling and taxonomic analyses

The panels were deployed at the two locations in March 2008, and the assemblages recruiting to and developing on the panels were monitored at different intervals until April 2015, i.e. seasonally over the first two years and annually throughout the next five years. The matt surface of all panels was photographed underwater with a high-resolution (300 dpi) NIKON D200 digital camera by SCUBA divers on each sampling occasion. The experimental panels were retrieved from the water after 3, 6, 9 and 12 months of continuous immersion over the course of two successive years: March 2008-March 2009 and March 2009March 2010 to record seasonal changes in the benthic assemblages. In March 2010, five new experimental units were deployed at one location (GDY) and the panels were sampled after $1,2,3,4$, and 5 years of immersion from 2010 to 2015 to track the multiannual development of sessile macrofauna and to assess the stability of the assemblages (Fig. 2). The panels were transported individually still immersed in water in purpose-built boxes to avoid drying the colonisers and loosing delicate fauna. The topsurfaces and undersurfaces of the panels were then examined under a binocular to identify sessile animals to the lowest possible taxonomic level. Since settlement on the edge surfaces of panels can be affected by additional biotic and abiotic disturbances (the "edge effect"; Underwood, 1997), only the internal square surface of $10 \mathrm{~cm} \times 10 \mathrm{~cm}$ was examined. The taxonomic nomenclature used followed the European Register of Marine Species (http://www.marbef.org/ data/erms.php). Individuals from each taxonomic group were then counted to assess species and individual abundance. The dominant barnacles Amphibalanus improvisus (Darwin, 1854) were dissected, and the soft tissue was air-dried at $55^{\circ} \mathrm{C}$ to a constant weight (for $48 \mathrm{~h}$ ) to determine their individual tissue weight and total biomass. The net growth of the barnacles was calculated as the increment of average tissue weight (for three panels) per month over a given period of continuous immersion. Each colony of colonial species like bryozoans or hydrozoans was counted as a single individual. In addition, the percentage area of the substratum covered by colonies of the cheilostomatid Einhornia crustulenta (Pallas, 1766) was measured with image analysis routines in Image J (https://imagej.nih.gov/ij/), and the bryozoanspecific growth rate $(\mu)$ was calculated as the increment of average areal coverage (for three panels) per month using the formula by Hermansen et al. (2001). Seasonal growth of sessile assemblages at successive sampling occasions was measured as change in (1) total abundance of faunal taxa; (2) total biomass of the numerically dominant crustacean A. improvisus; (3) the percentage area of the panel covered by colonies of E. crustulenta.

\section{Environmental variables}

Temperature $\left({ }^{\circ} \mathrm{C}\right.$ ) and light intensity (lux) in the overlying bottom water close to the experimental units were recorded automatically every $0.5 \mathrm{~h}$ using twochannel data loggers (Hobo Waterproof Temperature/ Light Pendant UA-002-64; 150-1200 nm) at two locations over the first two years of the experiment (March 2008-March 2010). The HOBO loggers have been proven useful for small-scale measurements when spatial coverage is needed in subsurface 


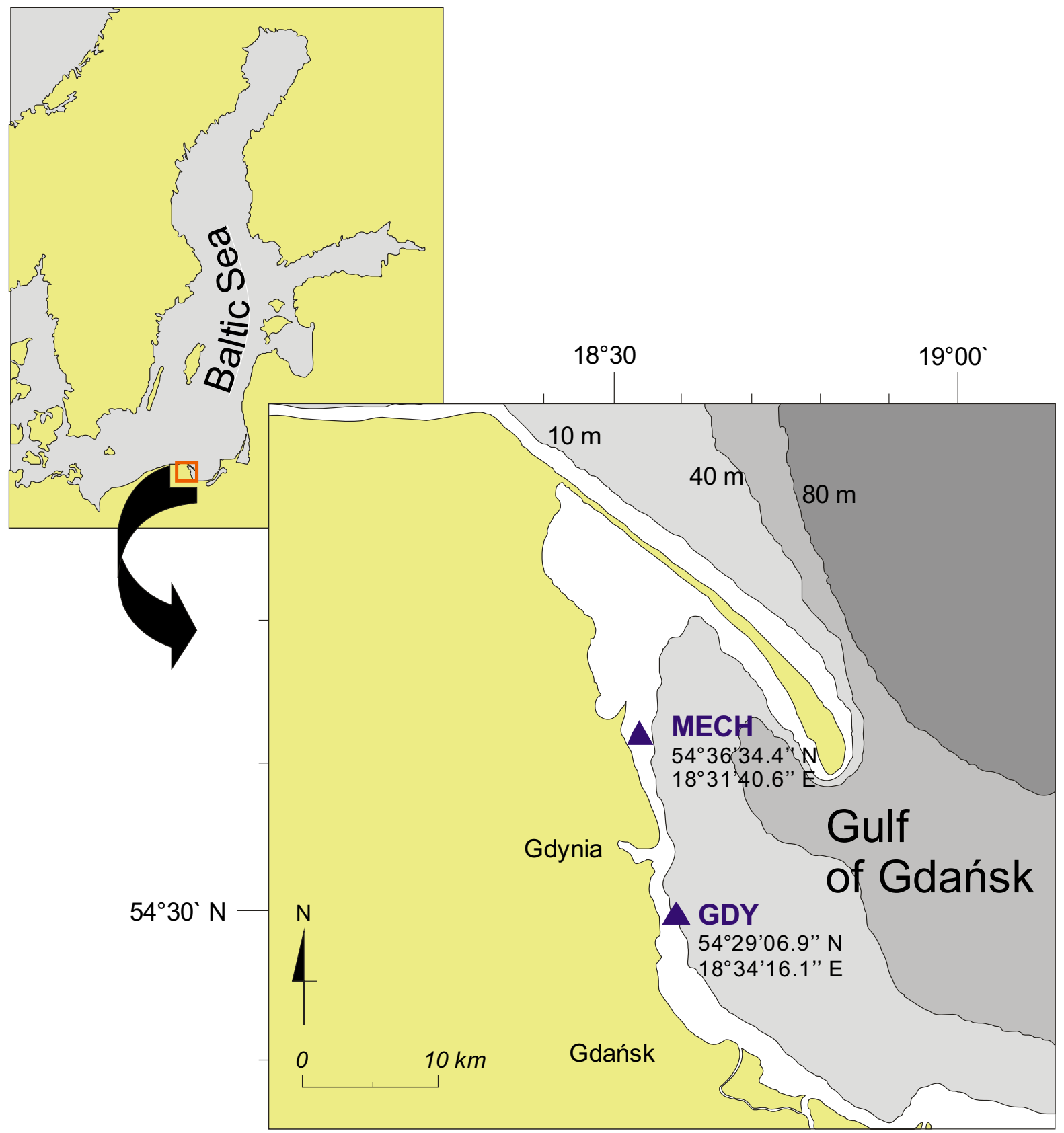

Fig. 1 Experimental locations in the Gulf of Gdańsk (southern Baltic Sea)

research in coastal areas (Long et al., 2012). The loggers were cleaned off biofouling organisms and debris (if any) and rinsed thoroughly with seawater by SCUBA divers every month to reduce measurement drift or sensor failure from fouling. Weekly data on gross primary production in the water column $\left(\mathrm{mg} \mathrm{C} \mathrm{m}^{-2}\right.$ day $\left.^{-1}\right)$ at the two locations between March 2008 and March 2010 was obtained from a predictive ecohydrodynamic model of the Baltic Sea (http://model.ocean.univ.gda.pl). In addition, the temperature and salinity of the overlying bottom water close to the experimental unit at GDY were measured using a WTW Multiline P4 meter equipped with an LF196 sensor at the beginning of immersion (March 2010) and at all year-end monitoring dates (March 2011-April 2015). 
Fig. 2 Experimental construction and schedule of panel retrieval

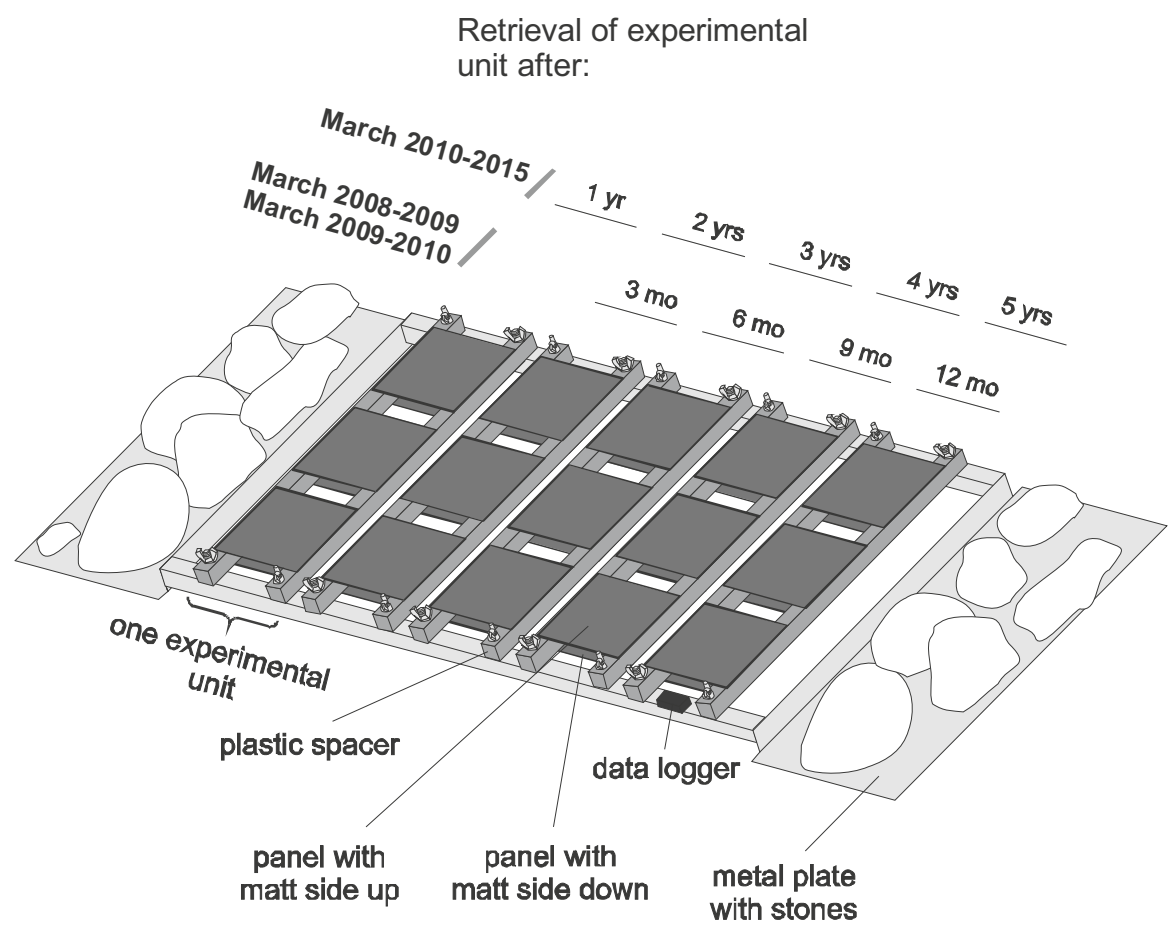

Data analysis

The abundance and biomass of the benthic organisms are expressed in units per $100 \mathrm{~cm}^{2}$ based on the examined surface area of the panels, while the cover of colonial species is expressed in \%. Water temperature and light intensity from the data loggers were averaged daily. Untransformed data were included in all statistical models followed by analyses of normality, i.e. the Kolmogorov-Smirnov test and a test of the goodness of fit as prerequisites. The significance of individual differences between two variables was checked with the paired $t$ test and among more variables with ANOVA using data of the same temporal resolution. When significant differences were obtained among more than three variables, Bonferroni correction at a critical probability $\dot{\alpha}=\alpha / c$ was employed for pairwise comparisons. The relationship between pairs of variables was estimated with correlation analysis. One-way analysis of similarity (ANOSIM) was conducted on square-root-transformed replicate faunal abundance to test the multivariate differences in species composition among locations, panel surfaces and immersion periods during the first two experimental periods, and the Bray-Curtis similarity matrix was used throughout using procedures in PRIMER 6.0 (http://www.primer-e.com/). Taxa contributing to dissimilarities among factor levels were defined by the similarities percentages routine (two-way crossed designed SIMPER with 90\% cut-off; Clarke \& Warwick, 2001). Multiple Regression Analysis was used to explain variation in the number of taxa and sessile faunal abundance in terms of environmental variables measured and variation of biomass of A. improvisus during successive immersion periods in terms of abundance and individual soft tissue dry weight of the barnacles. The level of significance for all tests was set at $P<0.05$.

\section{Results}

Environmental variables

The thermal and light conditions of the overlying bottom water at the two coastal locations, GDY and $\mathrm{MECH}$, over the first two years of immersion are described in detail in Sokołowski et al. (2017). Water temperature was higher at $\mathrm{MECH}$ (paired $t$ test, $t_{372}=7.54, P<0.001$; mean $\pm \mathrm{SE}, 10.3 \pm 6.1^{\circ} \mathrm{C}$, $n=743)$ than at GDY $\left(10.0 \pm 6.1^{\circ} \mathrm{C}, n=743\right)$, and it generally followed local meteorological conditions 
with increased values in summer (up to $23.4^{\circ} \mathrm{C}$ in July) and decreases in winter (down to $-0.5^{\circ} \mathrm{C}$ in January). Light conditions remained fairly similar at the two locations (paired $t$ test), but GDY tended to show higher light intensity (300 \pm 966 lux, $n=743$ ) than MECH (283 \pm 795 lux, $n=743)$. At both locations, the loggers were totally covered (i.e., the daily irradiance recorded was 0 lux) mainly in autumn and winter, when the development rate of fouling organisms is slow and the total number of coverage days was larger at GDY (127 day year ${ }^{-1}$ ) than at MECH (60 day year $^{-1}$ ). Since the weekly frequency of days of total light reduction did not increase with time (author's own observations) at one-month intervals as would be expected in the case of fouling, the deposition of resuspended particles from the bottom from wave action and bottom currents were, therefore, supposed to account primarily for logger coverage. Light intensity was also highly seasonal (ANOVA, $\left.F_{24,764}=964.8, P<0.001\right)$ with the highest luminous intensity up to 3800 lux during the growing period (March-October) and low light in winter and spring (November-March). Gross primary production in the water column did not differ between locations (paired $t$ test, $77.5 \pm 10.3$ and $86.1 \pm 13.0 \mathrm{mg} \mathrm{C} \mathrm{m}^{-2}$ day $^{-1}$ both $n=154$ at MECH and GDY, respectively, for the entire 2-year experimental period), but it did show apparent temporal variations (ANOVA, $\left.F_{24,764}=11.3, \quad P<0.001\right)$. Peak phytoplanktonic blooms occurred in March (up to $700 \mathrm{mg} \mathrm{C} \mathrm{m}^{-2}$ day $^{-1}$ ) followed by gradual decreases in summer and autumn to minimum in winter $\left(0 \mathrm{mg} \mathrm{C} \mathrm{m}^{-2} \mathrm{day}^{-1}\right)$. Salinity ranged from 5.8 to 8.4 and from 5.8 to 7.5 at MECH and GDY, respectively, but it did not differ statistically between locations (paired $t$ test) or over time (ANOVA).

Water temperature and salinity at GDY at all the year-end monitoring dates (March 2010-April 2015) ranged from $6.2^{\circ} \mathrm{C}$ in 2010 to $13.4^{\circ} \mathrm{C}$ in 2013 and between 5.4 in 2013 and 7.2 in 2015, respectively, and were within the range of thermo-saline conditions that were recorded during the first two years of the experiment.

\section{Panel immersion}

Despite long ice cover in winter 2008-2009 and a violent storm with extremely strong winds (gusts up to $130 \mathrm{~km} \mathrm{~h}^{-1}$ ) from the east (generating large waves along the western coast of the Gulf of Gdańsk) in October 2009, the metal frames housing the experimental panels did not move on the sea bottom and were not damaged by ice impact. All the panels survived and were collected after a nominal immersion time of three months in 2008-2010 and one year in 2010-2015. Due to temporary adverse meteorological conditions and logistic constraints, the retrieval dates differed, however, across the seasons and years, the mean immersion periods were $89 \pm 11$ day $(n=8)$ for the seasonal survey and $374 \pm 28$ day $(n=5)$ during the 5-year immersion.

Taxonomic richness during yearly immersions

A total of five sessile faunal taxa were identified on the experimental panels representing five phyla: the bivalve Mytilus trossulus Gould, 1850 (Mollusca); the crustacean Amphibalanus improvisus (Arthropoda); Einhornia crustulenta (Bryozoa); polyps of Hydrozoa and Scyphozoa (Cnidaria). During the oneyear immersions between 2008 and 2010, the taxonomic richness varied significantly among panel surfaces, locations and over time (ANOVA; Table 1a). On a single panel taxonomic richness ranged from 0 taxa to a maximum of 4 taxa and tended to be higher (though not statistically different) at MECH (paired $t$ test; mean \pm SE; $1.8 \pm 0.2, n=48$ ) than at GDY $(1.5 \pm 0.2, n=48)$. More sessile taxa were present on the undersurfaces (paired $t$ test, $t_{48}=-3.36, P=0.001 ; 2.1 \pm 0.2, n=48$ ) than on the topsurfaces of the experimental panels $(1.3 \pm 0.2$, $n=48$ ). Mussels, barnacles, bryozoans and scyphopolyps were recorded at both locations and panel surfaces, whereas hydroid polyps developed exclusively on the undersurfaces at GDY. In addition, a number of taxa varied temporally, and species richness showed a similar seasonal pattern on the panel topsurfaces and undersurfaces at both locations: MECH (correlation analysis, $r^{2}=0.77, P=0.004$, $n=8$ ) and GDY (correlation analysis, $r^{2}=0.75$, $P=0.006, n=8$ ). No sessile fauna was present on any panel surface after the three-month immersion. At $\mathrm{MECH}$, the maximum taxonomic richness was recorded after the 12-month immersion (up to $3.7 \pm 0.3$ and $2.0 \pm 0.0$ on the panel undersurfaces and topsurfaces, respectively), while at GDY, the largest number of taxa $(4.0 \pm 0.0)$ occurred after the 12-month immersion on the undersurfaces and after 
Table 1 Results of ANOVA for testing the significance of panel surface, immersion time and location on a number of taxa and total abundance of sessile fauna on the experimental panels retrieved from water after 3, 6, 9 and 12 months of continuous immersion during two successive years: March 2008-March 2009 and March 2009-March 2010 (a) and the significance of panel surface and immersion time on a number of taxa and total abundance of sessile fauna on the panels after 1, 2, 3, 4 and 5 year of immersion (from March 2010 to April 2015) in the Gulf of Gdańsk (southern Baltic Sea)

\begin{tabular}{|c|c|c|c|c|c|c|}
\hline & \multicolumn{3}{|c|}{ No taxa } & \multicolumn{3}{|c|}{ Total abundance } \\
\hline & $\mathrm{df}$ & $F$ & $P$ & $\mathrm{df}$ & $F$ & $P$ \\
\hline \multicolumn{7}{|l|}{ (a) } \\
\hline Panel surface & 1 & 33.30 & $* * *$ & 1 & 1.79 & \\
\hline Immersion time & 3 & 61.00 & $* * *$ & 3 & 8.63 & \\
\hline \multirow[t]{3}{*}{ Location } & 1 & 4.08 & $*$ & 1 & 12.83 & \\
\hline & \multicolumn{3}{|c|}{ No taxa } & \multicolumn{3}{|c|}{ Total abundance } \\
\hline & $\mathrm{df}$ & $F$ & $P$ & $\mathrm{df}$ & $F$ & $P$ \\
\hline
\end{tabular}

(b)

$\begin{array}{lcccccc}\text { Panel surface } & 1 & 30.44 & * * * & 1 & 13.05 & * * \\ \text { Immersion time } & 4 & 0.89 & 4 & 3.68\end{array}$

the six-month immersion on the panel topsurfaces $(3.0 \pm 0.0)$. The results of Multiple Regression Analysis that tested the relationship between the number of taxa on each panel surface (dependent variables) and environmental data (independent variables) showed the positive effect of gross primary production on faunal assemblages on the panel undersurfaces $\left(b^{*}=0.72, P<0.01\right)$.

\section{Seasonal changes in growth of sessile fauna}

The abundance of sessile fauna varied across locations and among immersion periods (ANOVA; Table 1a), but it was similar on the two panel surfaces (paired $t$ test; mean $\pm \mathrm{SE} ; 62 \pm 13$ ind. $100 \mathrm{~cm}^{-2}$ and $45 \pm 8$ ind. $100 \mathrm{~cm}^{-2}$ both $n=48$ on the topsurfaces and undersurfaces, respectively). More numerous assemblages developed at MECH (paired $t$ test, $t_{48}=-3.22, P=0.002 ; 77 \pm 13$ ind $100 \mathrm{~cm}^{-2}$, $n=48)$ than at GDY $\left(31 \pm 6\right.$ ind. $100 \mathrm{~cm}^{-2}$, $n=48$ ). The composition of sessile assemblages differed significantly between locations (ANOSIM; $R=0.161, \quad P<0.003) \quad$ and panel surfaces
$(R=0.248, P<0.001)$ but not among immersion periods. SIMPER analyses comparing assemblages at GDY with those at MECH revealed a $67.6 \%$ dissimilarity level and identified barnacles as contributing most to the observed difference ( $>75.0 \%)$. Cirripeds also accounted primarily for the distinction between sessile fauna on the topsurfaces and undersurfaces of the experimental panels $(>72.0 \%)$ at a betweensurface dissimilarity level of $69.3 \%$. Regardless of panel location or surface, barnacles largely predominated the communities contributing up to $99.7 \%$ of the total abundance, and they drove temporal variation in the total abundance of sessile fauna (Fig. 3). Mussels occurred in higher numbers only on the topsurfaces at GDY after nine- and 12-month immersions (up to $50 \%$ of the total abundance). In most cases, the abundance of sessile fauna was the highest after the six-month immersion followed by a sharp reduction after nine months and an increase after 12 months. The exceptions were the undersurfaces at MECH in 2009-2010, when the abundance increased gradually with immersion time over the entire experimental period and panel topsurfaces at $\mathrm{MECH}$ in the same period, when maximum abundance occurred after nine months (Fig. 3). Multiple Regression Analysis did not reveal any significant effect of environmental data on the abundance of faunal assemblages on any panel surface.

The total biomass of A. improvisus increased overall with immersion time (ANOVA; Table 3; Fig. 4) which resulted from both increasing abundance (Fig. 3) and growing individual soft tissue dry weight (Fig. 4 insert) with the stronger effect of the latter (Multiple Regression Analysis $b^{*}=0.45$, $P<0.001$ and $b^{*}=0.77, P<0.001$ for abundance and tissue weight, respectively). At both locations, the pattern of temporal change in biomass was generally consistent from year to year and between panel surfaces, but it varied in magnitude between the two experimental periods (March 2008-March 2009 and March 2009-March 2010) with biomass being considerably greater on the topsurfaces (mean $\pm \mathrm{SE}$; $\left.207 \pm 27 \mathrm{mg} 100 \mathrm{~cm}^{-2}, n=15\right)$ than on the undersurfaces $\left(67 \pm 10 \mathrm{mg} 100 \mathrm{~cm}^{-2}, n=18\right)$ of the experimental panels at MECH. In addition, barnacle biomass differed statistically between locations. When two immersion periods and both panel surfaces are combined, markedly greater assemblages of A. improvisus developed at MECH $\quad(130 \pm 18 \mathrm{mg}$ 

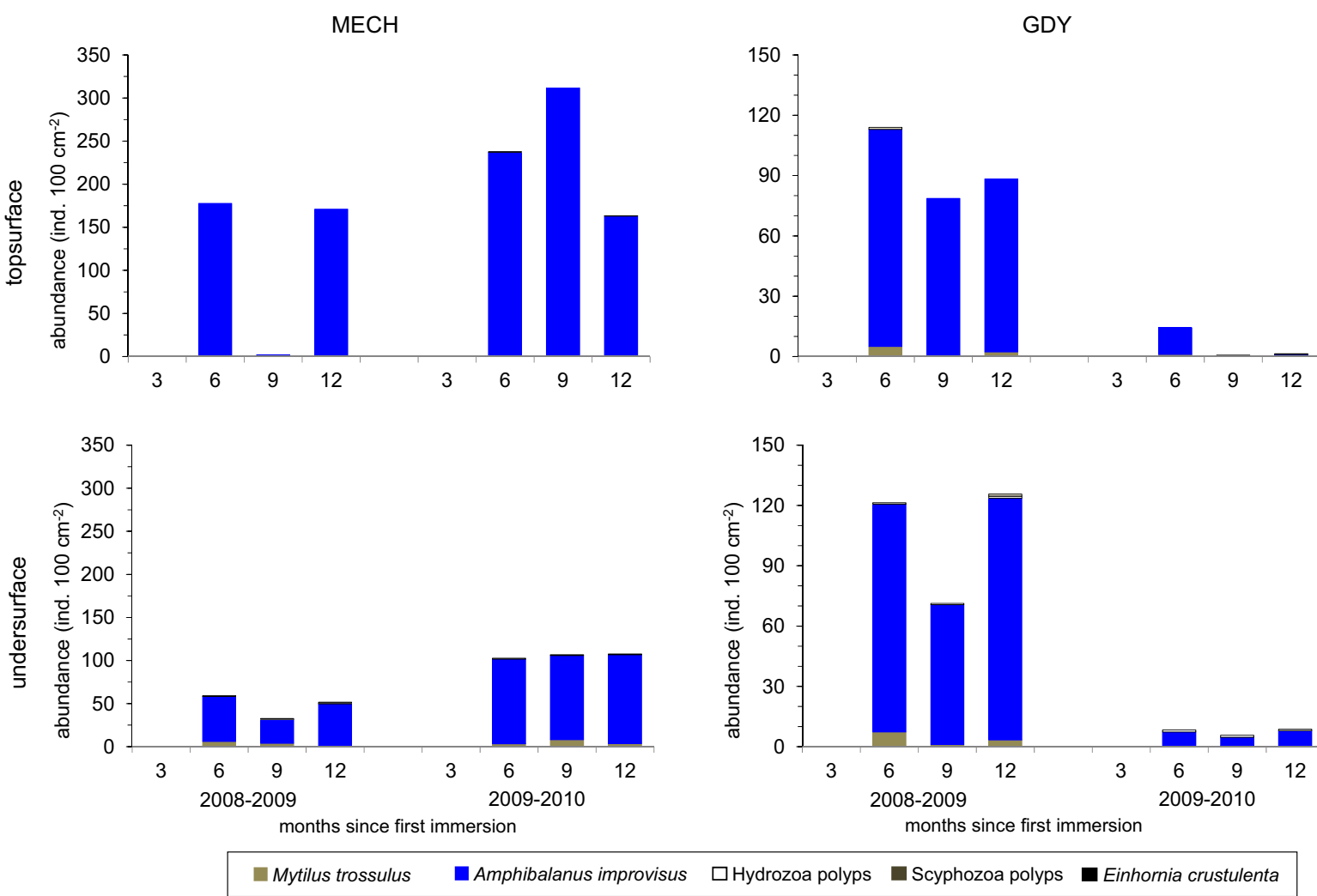

Fig. 3 Abundance of sessile fauna on topsurface and undersurface of experimental panels at two locations (MECH, GDY) in the Gulf of Gdańsk in two experimental periods: March 2008-March 2009 and March 2009-March 2010

$$
\begin{aligned}
& \left.100 \mathrm{~cm}^{-2}, \quad n=33\right) \text { than at GDY }(39 \pm 7 \mathrm{mg} \\
& \left.100 \mathrm{~cm}^{-2}, n=33\right) .
\end{aligned}
$$

The cirriped crustacean provided continuous data at both locations and was also suitable for the measurement of species-specific seasonal growth. Its individual soft tissue dry weight ranged from 0.45 to $1.74 \mathrm{mg}$ (Fig. 4 insert) and varied significantly between locations and over immersion time, but no interaction was observed between panel surfaces (ANOVA; Table 2). Larger individuals were generally recorded at $\mathrm{MECH}$ (paired $t$ test, $t_{33}=-3.20, P=0.002$; mean $\pm \mathrm{SE}$; $0.97 \pm 0.07 \mathrm{mg}, \quad n=33)$ than at GDY $(0.70 \pm$ $0.04 \mathrm{mg}, n=33$ ), which is consistent with geographical differences in the total biomass of $A$. improvisus. In contrast, the barnacles had fairly similar tissue weight on the topsurfaces (paired $t$ test; $0.85 \pm 0.07 \mathrm{mg}$, $n=30$ ) and the undersurfaces of the experimental panels $(0.82 \pm 0.06 \mathrm{mg}, n=36)$. When the two locations and panel surfaces were combined, tissue weight increased linearly with time reaching the maximum value after 12 months of continuous immersion. The net growth of the barnacles, which was calculated separately for each three-month immersion period as an increment of tissue weight per month, occurred in all seasons except the first three-month immersion in spring (Tables 3, 4). The greatest increases were noted during summer (up to $194.0 \mathrm{mg}$ month $^{-1}$ between the third and sixth months of immersion) and autumn (up to $256.5 \mathrm{mg} \mathrm{month}{ }^{-1}$ between the sixth and ninth months of immersion), but growth also apparently continued at lower rates throughout the winter (26.1-93.8 $\left.\mathrm{mg} \mathrm{month}^{-1}\right)$. The comparison of annual barnacle growth (i.e. tissue increment over the entire immersion period) on the different panel surfaces between March 2008 and March 2009 showed slightly higher growth rates on the panel undersurfaces (136.7 and $108.6 \mathrm{mg} \mathrm{month}^{-1}$ at MECH and GDY, respectively) than on the topsurfaces (112.4 and $96.3 \mathrm{mg} \mathrm{month}^{-1}$, respectively).

The development of the Einhornia crustulenta colony was also highly seasonal (ANOVA; Table 3) with detectable net growth on the undersurfaces in all 
Fig. 4 Biomass of the barnacle Amphibalanus improvisus on topsurface and undersurface of experimental panels after 3 , 6, 9 and 12 months of continuous immersion in two experimental periods: March 2008-March 2009 and March 2009-March 2010 at two locations (MECH, GDY). Inserts present individual soft tissue weight of the barnacles in the same experimental periods. Data are presented as mean $\pm \mathrm{SE}, n=3$
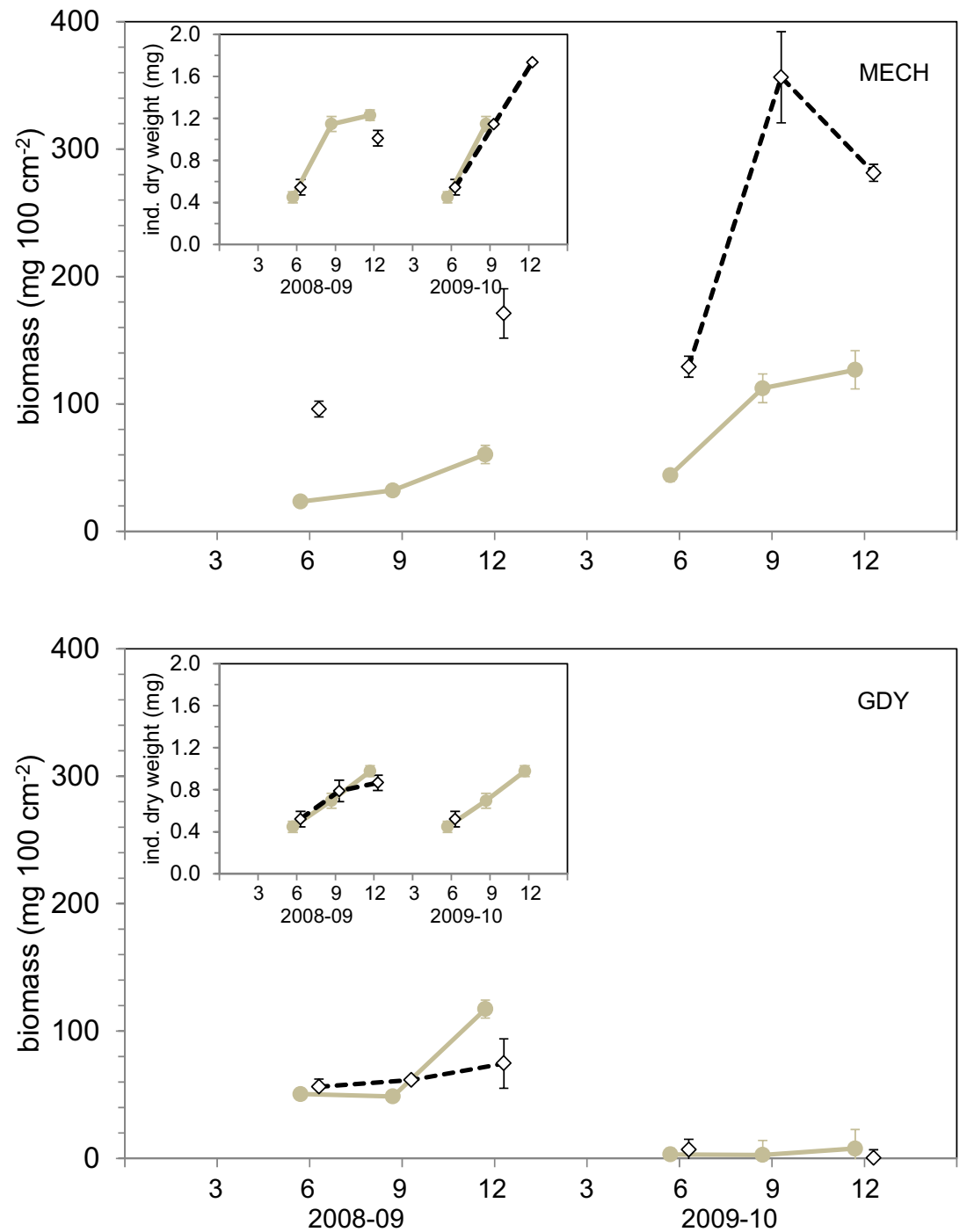

months since first immersion seasons except in the first three-month immersion (March-June). The overall areal coverage was not significantly different (paired $t$ test) between locations, but it tended to be greater at $\mathrm{MECH}$ (mean $\pm \mathrm{SE}$; $46.0 \pm 30.8$ and $64.0 \pm 26.5 \%$ in the first and second experimental period, respectively) than at GDY $(14.6 \pm 8.5$ and $29.2 \pm 20.9 \%)$. The pattern of seasonal variations was underlain by apparent differences at locations seasonally (Fig. 5). At GDY, the colonies of this bryozoan grew continually over nine months of immersion in both experimental periods with the greatest net growth rate in autumn (347 and $1392 \mathrm{~mm}^{2}$ month $^{-1}$ in the first and second experimental period, respectively) and an apparent decrease in area cover (from 49.9 to $29.9 \%$ ) only in winter 2009-2010. In contrast, the bryozoan assemblages at MECH grew more dynamically in summer (1920 and $2758 \mathrm{~mm}^{2}$ month $^{-1}$ in 2008 and 2009, respectively) when its area cover reached a maximum of $82.7 \%$ to decrease sharply in autumn to 11.1 and $45.2 \%$ in the first and second experimental period, respectively. In the first experimental period, net growth was again observed 
Table 2 Taxa contributing to the dissimilarity between faunal assemblages developing at Gdynia and Mechelinki and on topsurface and undersurface of the experimental panels based on the abundance square-root-transformed data

\begin{tabular}{|c|c|c|c|c|c|}
\hline \multirow{2}{*}{$\begin{array}{l}\text { Taxon } \\
\text { Group: site }\end{array}$} & \multicolumn{2}{|c|}{ Average abundance (ind. $100 \mathrm{~cm}^{-2}$ ) } & \multirow[t]{2}{*}{ Average dissimilarity } & \multirow[t]{2}{*}{ Diss/SD } & \multirow[t]{2}{*}{ Contribution (\%) } \\
\hline & GDY & $\mathrm{MECH}$ & & & \\
\hline Amphibalanus improvisus & 4.35 & 7.53 & 50.83 & 1.63 & 75.22 \\
\hline Mytilus trossulus & 0.70 & 1.39 & 11.49 & 0.81 & 17.01 \\
\hline Group: surface & Topsurface & Undersurface & & & \\
\hline Amphibalanus improvisus & 6.57 & 5.31 & 50.27 & 1.69 & 72.57 \\
\hline Mytilus trossulus & 1.07 & 1.02 & 10.55 & 0.80 & 15.23 \\
\hline Einhornia crustulenta & 0.06 & 0.69 & 6.54 & 0.85 & 9.43 \\
\hline
\end{tabular}

Data on abundance (average value for two locations and all months) are given as untransformed values

Table 3 Results of ANOVA for testing the significance panel surface, immersion time and location on total biomass, individual soft tissue dry weight and net growth rate of the barnacle Amphibalanus improvisus and on areal coverage of the bryozoan Einhornia crustulenta on the experimental panels retrieved from water after 3, 6, 9 and 12 months of continuous immersion during two successive years: March 2008-March 2009 and March 2009-March 2010 in the Gulf of Gdańsk (southern Baltic Sea)

\begin{tabular}{|c|c|c|c|c|c|c|c|c|c|}
\hline & \multicolumn{3}{|c|}{ Panel surface } & \multicolumn{3}{|c|}{ Immersion time } & \multicolumn{3}{|c|}{ Location } \\
\hline & df & $F$ & $P$ & df & $F$ & $P$ & df & $F$ & $P$ \\
\hline \multicolumn{10}{|c|}{ Amphibalanus improvisus } \\
\hline Biomass & 1 & 6.26 & $*$ & 3 & 8.83 & $* * *$ & 1 & 17.97 & $* * *$ \\
\hline Tissue weight & 1 & & & 3 & 61.41 & $* * *$ & 1 & 3.41 & $*$ \\
\hline Growth rate & 1 & & & 3 & 16.02 & $* * *$ & 1 & & \\
\hline \multicolumn{10}{|c|}{ Einhornia crustulenta } \\
\hline Areal coverage & \# & & & 3 & 7.02 & $* * *$ & 1 & 7.37 & $* *$ \\
\hline
\end{tabular}

*** $P<0.001$, ** $P<0.01$, * $P<0.05$, blank cel-not significant effect

\# The bryozoan developed exclusively on panel undersurface

Table 4 Growth rate (changes in individual soft tissue dry weight over a given time, mg month ${ }^{-1}$ ) of Amphibalanus improvisus on topsurface and undersurface of the experimental panels in two experimental periods: March 2008-March 2009 and March 2009-March 2010 at two locations, MECH and GDY, in the Gulf of Gdańsk (southern Baltic Sea)

\begin{tabular}{|c|c|c|c|c|c|c|c|c|}
\hline \multirow{2}{*}{$\begin{array}{l}\text { Experimental period } \\
\text { Season } \\
\text { (months of } \\
\text { immersion) }\end{array}$} & \multicolumn{4}{|c|}{ 2008-2009 } & \multicolumn{4}{|c|}{ 2009-2010 } \\
\hline & $\begin{array}{l}\text { Summer } \\
(3-6)\end{array}$ & $\begin{array}{l}\text { Autumn } \\
(6-9)\end{array}$ & $\begin{array}{l}\text { Winter } \\
(9-12)\end{array}$ & $\begin{array}{l}\text { Entire period } \\
(3-12)\end{array}$ & $\begin{array}{l}\text { Summer } \\
(3-6)\end{array}$ & $\begin{array}{l}\text { Autumn } \\
(6-9)\end{array}$ & $\begin{array}{l}\text { Winter } \\
(9-12)\end{array}$ & $\begin{array}{l}\text { Entire period } \\
(3-12)\end{array}$ \\
\hline \multicolumn{9}{|l|}{$\mathrm{MECH}$} \\
\hline Topsurface & 181.7 & & 33.7 & $112.4 *$ & 181.7 & 200.3 & 196.9 & 193.0 \\
\hline Undersurface & 149.7 & 232.3 & 28.1 & 136.7 & 165.0 & 217.0 & & \\
\hline \multicolumn{9}{|l|}{ GDY } \\
\hline Topsurface & 173.6 & 89.1 & 26.1 & 96.3 & 194.0 & & & \\
\hline Undersurface & 149.1 & 82.8 & 93.8 & 108.6 & 181.6 & 256.5 & 176.0 & 144.2 \\
\hline
\end{tabular}

Empty cel—no individuals. Barnacles did not develop on any panel surface at any location after the first 3 months immersion (spring)

* Annual growth increment was calculated only when individuals were present after 12 months immersion

Bold values indicate the entire immersion period 


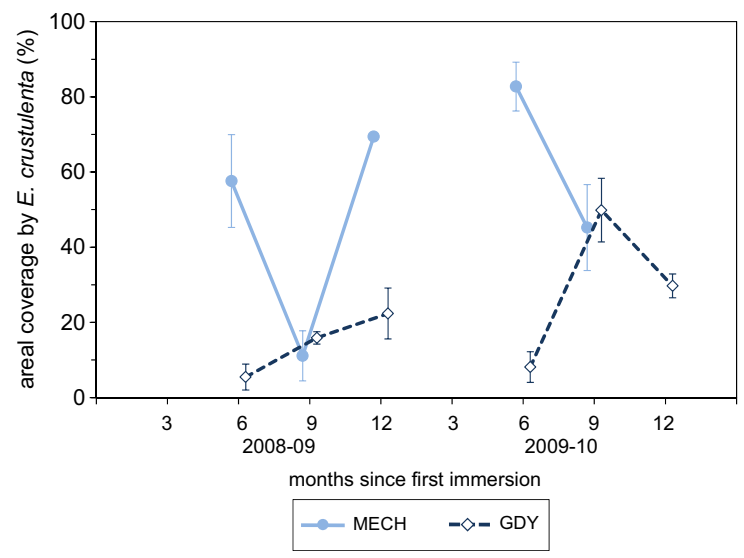

Fig. 5 Total areal coverage by colony of the cheilostome bryozoan Einhornia crustulenta on undersurfaces of experimental panels after 3, 6, 9 and 12 months of continuous immersion in two experimental periods (March 2008-March 2009 and March 2009-March 2010) at two locations (MECH, GDY). Data are presented as mean $\pm \mathrm{SE}, n=3$

between December and March (winter) while no colonies developed on panel undersurfaces in the second experimental period (2009-2010). Throughout the entire immersion and in two experimental periods, the growth of bryozoan colonies was greater at MECH (paired $t$ test, $t_{15}=3.92, P<0.001$; mean $\pm \mathrm{SE}$; $53.2 \pm 7.3 \%, n=15)$ than at GDY $(21.9 \pm 4.0 \%$ $n=18$ ), which indicated greater environmental and/ or biotic disturbances in the more dynamic and lesssheltered location at GDY.

Multi-annual changes in the growth of sessile fauna

The same five faunal taxa, including the bivalve $M$. trossulus, the cirriped A. improvisus, the bryozoan $E$. crustulenta and polyps of Hydrozoa and Scyphozoa, occurred on the experimental panels over five years of immersion as during seasonal sampling between March 2008 and March 2010. Overall, significantly fewer taxa were recorded on the panel topsurfaces (paired $t$ test, $t_{15}=-5.52, P<0.001$; mean $\pm \mathrm{SE}$; $1.5 \pm 0.3, n=5)$ than on the undersurfaces (mean $\pm \mathrm{SE} ; 3.5 \pm 0.6, n=5$ ) with hydrozoids and scyphozoids present exclusively on the latter (Table 1; Fig. 6). On both panel surfaces, the taxonomic richness of sessile assemblages varied markedly over the first two years to reach a fairly stable value of approximately 3.7 and 2.0 taxa on the undersurfaces and topsurfaces, respectively, after three years of immersion. This multi-annual pattern of changes in species richness was not reflected, however, by abundance which increased progressively throughout the entire period of immersion. The maximum abundance of $106 \pm 18$ ind. $100 \mathrm{~cm}^{-2}(n=3)$ and $22 \pm 5$ ind. ind. $100 \mathrm{~cm}^{-2}(n=3)$ on the panel undersurfaces and topsurfaces, respectively, was subsequently observed after five years, suggesting gradual occupancy of free ecological niches by benthic fauna. The sessile assemblages were more abundant on panel undersurfaces (paired $t$ test, $t_{15}=-3.61, P=0.001$; $47 \pm 10$ ind. $100 \mathrm{~cm}^{-2}$ ) than on the topsurfaces $\left(11 \pm 3\right.$ ind. $\left.100 \mathrm{~cm}^{-2}\right)$ and were clearly dominated by $A$. improvisus which contributed the most (from 53.8 to $97.2 \%$ ) to the total faunal abundance over the majority of immersion time. Divergent community structure was observed only during the initial recruitment phase, i.e. after two years of immersion on panel undersurfaces and after one year of immersion on topsurfaces when scyphozoan polyps and mussels comprised 44.4 and $50.0 \%$ of total abundance, respectively. It is noteworthy that the contribution of A. improvisus to the total sessile fauna abundance increased with immersion time on both panel surfaces (correlation analysis both $P<0.04$ ) which is indicative of progressive growth of the balanid assemblages. Although the abundance of $M$. trossulus on the panels occasionally reached as much as 6 ind. $100 \mathrm{~cm}^{-2}$, mussels generally occurred in low numbers and in variable shell size (author's own observations) on most sampling occasions.

Thus, the encrusted cirriped was the only species for which continuous data on biomass were able to track multi-annual variation over five years of immersion. Balanid biomass was strongly depended on panel surface (ANOVA, $F_{1,30}=6.91, P=0.014$ ) and time of immersion (ANOVA, $F_{4,30}=4.02$, $P=0.012$ ), with higher biomass recorded on panel undersurfaces (mean $\pm \mathrm{SE}$; $68 \pm 16 \mathrm{mg} 100 \mathrm{~cm}^{-2}$, $n=15)$ than on topsurfaces $\left(23 \pm 7 \mathrm{mg} 100 \mathrm{~cm}^{-2}\right.$, $n=15$ ). The Bonferroni post hoc test showed a significant difference in biomass only between panels which were immersed for one and five years. The biomass increased progressively during most of the immersion period, but it followed different temporal patterns on the two panel surfaces. On the undersurfaces, after an initial large increase up to $59.5 \mathrm{mg}$ $100 \mathrm{~cm}^{-2}$ over the first two years of immersion, the 
Fig. 6 Abundance of sessile fauna on topsurface and undersurface of experimental panels after 1 , 2, 3, 4 and 5 year of continuous immersion (from March 2010 to April 2015) at GDY. Inserts present number of sessile faunal taxa in the same experimental period. Data are presented as mean $\pm \mathrm{SE}, n=3$

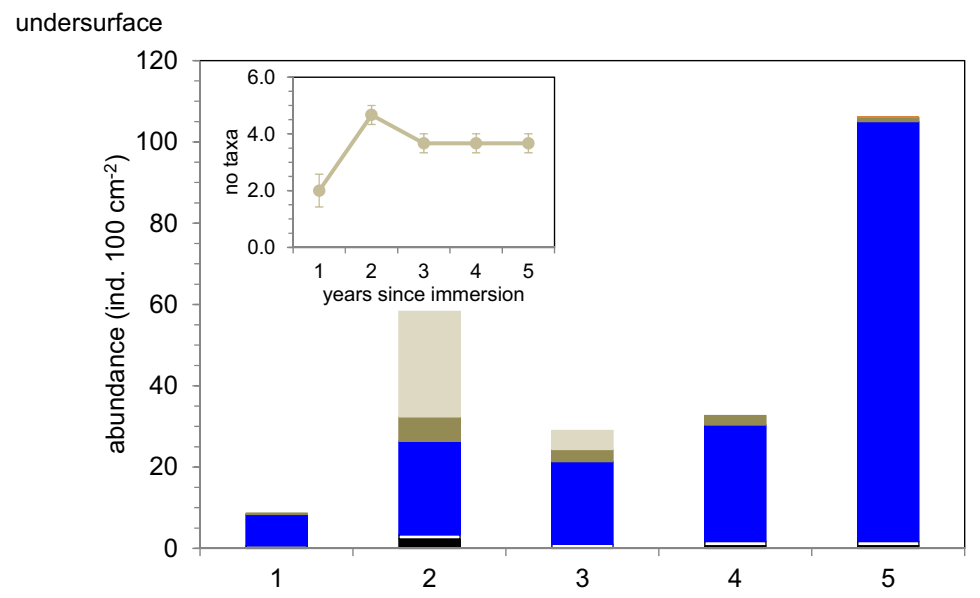

topsurface

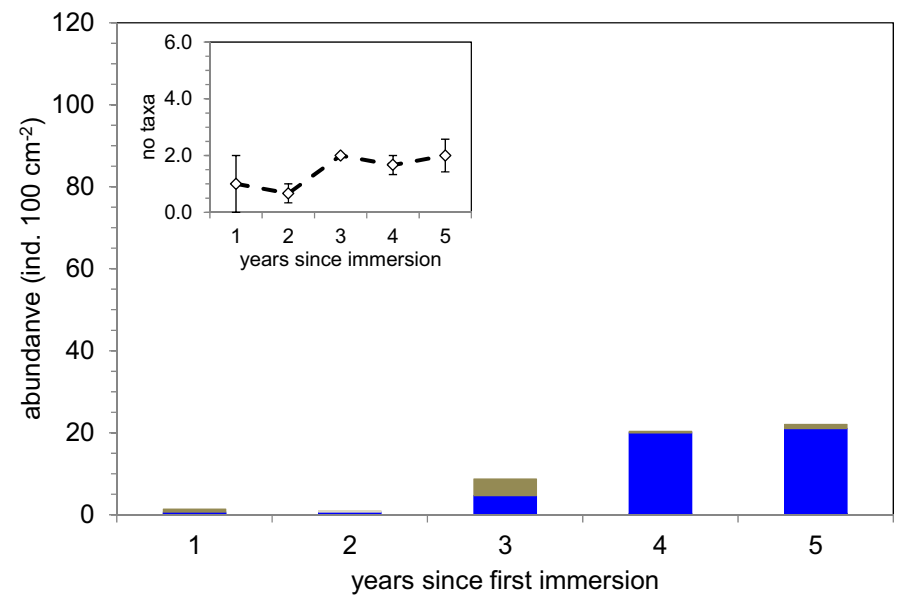

Mytilus trossulus

Amphibalanus improvisus $\square$ Hydrozoa polyps

Scyphozoa polyps

Einhornia crustulenta

biomass remained stable until the fourth year to increase again up to $157.8 \mathrm{mg} 100 \mathrm{~cm}^{-2}$ on the final year-end monitoring day. On the panel topsurfaces, in contrast, the biomass increased to $62.2 \mathrm{mg} 100 \mathrm{~cm}^{-2}$ during the fourth year only to decrease in the final year of immersion (Fig. 7a).

The presence of the bryozoan E. crustulenta on the panel topsurfaces was accidental. Only on one panel after one year and one after five years of continuous immersion did these bryozoans develop initial colonies of relatively small coverage (mean $\pm \mathrm{SE}$; $1.8 \pm 1.3 \%, n=2$ ). The total areal covered by $E$. crustulenta on the panel undersurfaces increased notably over the first two years of immersion, reaching a mean coverage of $96.0 \pm 2.7 \%$ at the end of the second year, and it remained fairly stable throughout the remainder of the study period (96.0-100.0\%). The maximum growth rate was thus detected during the first and second years (69 and $27 \%$ of the available substratum year ${ }^{-1}$, respectively, which corresponds to 0.0239 and 0.0009 day $^{-1}$ of the specific growth rate, respectively). There was, however, a negative net increase (-9\%), i.e. a decline in colony areal cover, in the fourth year of immersion, coinciding with a change in balanid biomass (Fig. 7a), but after five years total coverage reached $100.0 \%$ (Fig. $7 b$ ).

\section{Discussion}

The applicability of artificial substrates such as plastic plates and concrete units as surrogates for natural 
(a)

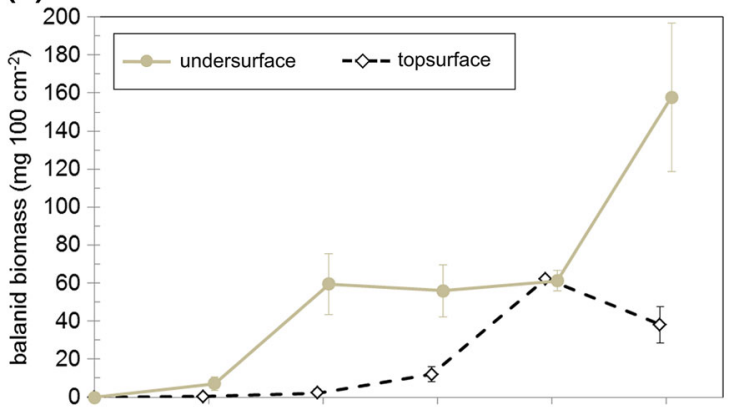

(b)

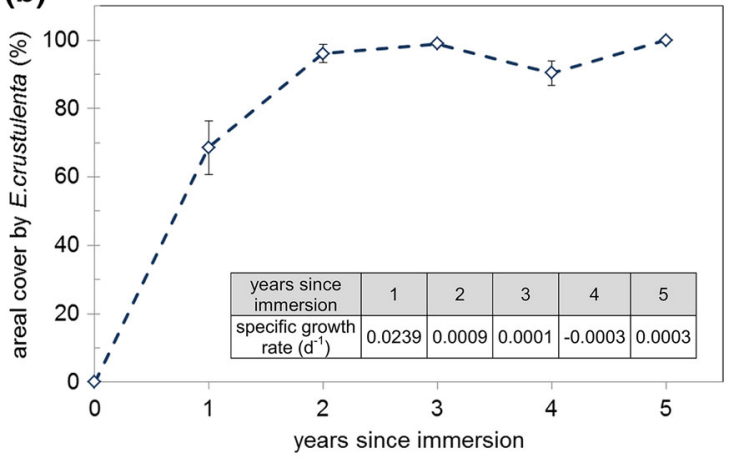

Fig. 7 Biomass of the barnacle Amphibalanus improvisus on topsurface and undersurface of experimental panels (a) and total areal coverage by colony of the cheilostome bryozoan Einhornia crustulenta on panel undersurface (b) after 1, 2, 3, 4 and 5 year of continuous immersion (from March 2010 to April 2015) at GDY. Data are presented as mean $\pm \mathrm{SE}, n=3$. Insert in figure b presents specific growth rate of $E$. crustulenta in the succeeding years since immersion

geological (rocks, gravel, rocks, dropstones) or biogenic structures (shells, reefs, wooden pieces) is still debated (e.g. Svane and Petersen, 2001; Qvarfordt et al., 2006). Although recruitment and the subsequent development of epifaunal assemblages on portable artificial substrates have been shown to differ from those on natural habitats in a few studies (Smith \& Rule, 2002; Tyrrell \& Byers, 2007), submerged Perspex panels have been used successfully in many coastal environments, thanks to relative ease of handling and the homogeneity of the recruitment surface (e.g. Andersson et al., 2009; Kukliński et al., 2013). Nevertheless, caution is required in interpreting the ecological results obtained when using artificial substrates and developing insights which such studies provide to the current understanding of colonisation and succession processes.
Factors driving the seasonality of colonisation and growth patterns of sessile macrofaunal communities $\left(\mathrm{H}_{01}\right)$

The artificial hard substrate in the brackish southern Baltic Sea developed relatively poor assemblages consisting of only five sessile taxa which is consistent with the overall impoverished taxonomic structure of benthic biota in this water basin (Bonsdorff, 2006). Naturally, low diversity of the resident epibenthic assemblages likely reduces interspecific competition for free space and food resources both at the initial stage of recruitment and later during successional development. The settlement process is enhanced, in turn, by the high dispersion potential of abundant planktonic and/or benthic larvae over a large distance by water movements (Robins et al., 2013) and the massive production of organic biofilm on shallow substrates (Sokołowski et al., 2017). At two coastal locations in the Gulf of Gdańsk, experimental panels were occupied by numerous recruits of all taxa recorded (except Hydrozoa polyps) as soon as after three months of immersion (Fig. 3). The occupation of free space was probably achieved by the high density of recruitment rather than by competitive interaction (Bowden et al., 2006). Because a thick biofilm layer on the panels which was formed by sedimented particles, bacteria and microphytobenthos in early spring and persisted as the earliest successional stage over the full vegetative season (author's own observations) and all sessile fauna co-occurred during most of the immersion period, no clear sequence of species that successively colonised the substrate was detected.

In comparison to other temperate systems of higher species richness, where initial colonists prepare the space for secondary recruits and hierarchical competition is an important factor determining the taxonomic composition of assemblages (Todd, 1998; Bowden et al., 2006), the development of sessile fauna on empty hard substrates in the Baltic is a less complex process. The advantage of one species over another is rather related to species-specific settlement timing and the growth rates of recruits while competitive interactions are of lesser importance. This is particularly so since most benthic species do not possess many natural competitors, and there is low interspecific overlap in the basic niche dimensions (diet and space) (Leppäkoski et al., 2002). It is therefore likely that the overwhelming dominance of barnacles A. improvisus 
resulted from the early recruitment period that usually precedes the settlement of mussels and other invertebrates such as bryozoans and hydroids (Sokołowski et al., 2017). A similar phenomenon was also reported in other Baltic regions, e.g. in the Kalmar Sound and in the Askö area along the Swedish east coast (Qvarfordt et al., 2006) and in the Kiel Fjord (Dürr \& Wahl, 2004), and on the rocky coast of northern Chile (Pacheco et al., 2010). In the Baltic Sea, A. improvisus is usually an initial coloniser of hard substrate with the potential to use free space efficiently (Qvarfordt et al., 2006) and to have a competitive advantage on smooth surfaces as its own presence can enhance the settlement of the same species (Andersson et al., 2009). The successful development of barnacles can also be attributed to its sustained growth in all seasons, leading to the largest biomass after 12 months of immersion on both panel surfaces at the two locations. The monthly increment of individual soft tissue was highest in summer and autumn, but net growth also continued at low rates in winter (Table 4). Evidence of continuing growth throughout the year (Fig. 4) implies that the ability to exploit limited winter resources in very shallow areas (from nanoplankton, resuspended particles or other sources) could be an adaptive advantage. In addition, when the substrate surface suitable for recruitment is relatively large, barnacles effectively outnumber mussels leading to barnacle-dominated communities (Navarrete \& Castilla, 1990). Mussels Mytilus trossulus constituted a numerically important component of the sessile assemblages (reaching up 50\% of the total faunal abundance) only on the panel topsurfaces at GDY after nine and 12 months of immersion (Fig. 3). Periodic increases in the relative abundance of mussels are probably related to the better resistance of the bivalves to physical perturbations at the less-sheltered GDY location. The negative influence of mussels on the settlement of other sessile species on the topsurfaces through competitive exclusion, a process that is well described in marine systems of higher taxonomic richness (Wootton, 1994), can be omitted as a potential interacting mechanism because mussel abundance was relatively low $\left(0.3\right.$ ind. $\left.100 \mathrm{~cm}^{-2}\right)$, leaving a lot of free space on the panels.

In most cases, after initial numerous panel occupation in summer, the abundance of sessile faunal assemblages decreased notably in winter to then redevelop in spring. This general pattern was also evident in the percentage cover of panels by the bryozoans at $\mathrm{MECH}$ with high aerial coverage after six and 12 months of immersion and an apparent reduction after nine months (Fig. 5). The seasonal dynamics of the faunal abundance and bryozoan colonies observed followed temporal variations in gross primary production in the water column highlighting the importance of phytoplankton development for reproduction, larval dispersal and the settlement of hardbottom fauna (Sokołowski et al., 2017). Spawning in most benthic species in the Gulf of Gdańsk is initiated by a coincidental rise in water temperature and concentration of phytoplankton which serves as an important energy source for planktonic larvae and recruits as well as for juveniles and adults (Wołowicz et al., 2006). All faunal species encountered during succession were suspension feeders that exploit primary production (phytoplankton, macroalgae and sediment detritus) for individual growth and community/colony development. Because of different food selection related to particle size and nutritional value (Grall et al., 2006; Pacheco et al., 2010) and the excessive availability of planktonic food in this highly eutrophic system, however, interspecific suppression by competing for food resources and/or possibly by feeding on early life history stages is limited in the southern Baltic. The winter decline in faunal assemblages on the experimental panels was caused presumably by physical disturbance, including severe actions of shoaling waves and enhanced resuspension of sediment particles during stormy weather.

Effect of substrate orientation on sessile benthic fauna $\left(\mathrm{H}_{02}\right)$

Both seasonal and multi-annual surveys provide evidence of the effect of panel orientation (topsurface vs. undersurface) on sessile macrofauna assemblages on horizontal hard substrates with a consistent pattern of species richness and abundance. Apparently, more diverse and numerous assemblages developed on the panel undersurfaces which are subjected to reduced physical and biological disturbances over time. The undersurfaces of the experimental panels were assumed to be more protected from sedimentation of suspended and resuspended particles, irradiance and direct wave action, thus they offered more sheltered conditions for settlement and growth. Although some species such as $M$. trossulus can actively develop at 
high deposition and its recruitment on upward facing substrates can be promoted by the presence of macroalgae (Seed \& Suchanek, 1992; Sokołowski et al., 2017), in this study, most sessile taxa preferred the panel undersurfaces. Hydrozoan polyps occurred exclusively on the panel undersurfaces, the encrusting bryozoan E. crustulenta developed mostly on the undersurfaces, while the barnacle A. improvisus was present on both panel surfaces. Bryozoan colonies confined to lower, hidden surfaces have been observed widely in many temperate and sub-polar ecosystems, e.g. Irish coastal waters (Maughan, 2001), southern Argentina (Centurión \& Gappa, 2011) and northern Chile (Pacheco et al., 2010). The cheilostome bryozoan exhibits a notable preference for hard substrates sheltered from sedimentation to avoid clogging (Maughan, 2001). It is also possible that the selective settlement of E. crustulenta on the undersurfaces is induced by geotropic and phototropic responses of its long-lived cyphonaute larvae (Glasby, 1999). The contrasting effects of panel orientation were observed for cirriped biomass with higher values on panel topsurfaces in the first two years of immersion and the opposite being recorded during the multi-annual immersion. Reasons explaining the observed differences could be attributed to differences in total barnacle abundance which together with individual growth rates were key factors controlling the biomass of A. improvisus on the panels.

Development rate of benthic community $\left(\mathrm{H}_{03}\right)$

The long immersion of the experimental panels over five years did permit tracking the multi-annual development of sessile macrofaunal assemblages on a hard substrate in the coastal zone of the southern Baltic Sea. In addition, the span of the survey period was probably long enough to judge whether the species composition of benthic assemblages achieved a later (stable) successional stage. According to classical successional theory, the degree of community stability can be assessed when an observation period is comparable to the generation time of component species and it is sufficiently long so that perturbations will have had a chance to occur at different intensities (Connell \& Slatyer, 1977). Since basic descriptors of community structure per se do not indicate the successional stage of developing community (Picket, 1976), the period of time during which benthic assemblages become fairly stable and convergent towards the communities inhabiting neighbouring areas were used in this study to assess community establishment rates. Benthic assemblages on artificial panels reached a stable taxonomic richness of approximately 3.7 and 2.0 taxa on the undersurfaces and topsurfaces, respectively, within three years of immersion and showed constancy over the subsequent two years. In most cases, the faunal assemblages on the final year-end monitoring days consisted largely of the same sessile taxa that had recruited seasonally on the panels during continuous immersion in the first two experimental years, so there was little turnover of species. After three years, the experimental assemblages resembled natural hardbottom assemblages in the vicinity of the Redłowo Cliff (the Gulf of Gdańsk) including five taxa typical for stones, boulders and gravel (Smoła, 2012). The observed temporal trend of taxonomic richness suggests that the macrofaunal assemblages on the panels achieved the late benthic successional stage leading ultimately to mature communities (Connell \& Slatyer, 1977) and the convergence rate (defined as the time necessary for developing communities to converge to the surrounding natural community) is around three years. A 27-month convergence rate of community composition was also recorded for subtidal benthic macrofauna on artificial hard substrates in northern Chile (Pacheco et al., 2010).

Similar temporal dynamics were recorded for the cheilostome bryozoan colonies which occupied nearly the whole available substrate (areal cover 96\%) as soon as two years of continuous immersion on the panel undersurfaces and remained fairly stable during subsequent years (Fig. 5). Such a development pattern indicates the successful growth and efficient occupancy of free space on the panels within a period of two years. The specific growth rate of $E$. crustulenta during the first year of immersion $\left(0.024\right.$ day $\left.^{-1}\right)$, i.e. when free space was unlikely to be limiting, was lower than those measured under laboratory conditions for other temperate species from the coastal waters of Denmark (approximately $0.073 \mathrm{day}^{-1}$; Hermansen et al., 2001) and of Wales (0.066 day ${ }^{-1}$; Amui-Vedel et al., 2007), but notably faster than those observed in the Adriatic Sea $\left(0.009\right.$ day $\left.^{-1}\right)$ and the Arctic (0.004 day $^{-1}$, data recalculated from Kukliński et al., 2013). Einhornia crustulenta is a brackish water specialist (Nikulina \& Schäfer, 2006) with an opportunistic life strategy and high potential for the colonisation of hard 
substrate protected from direct sedimentation. In the low-diversity Baltic Sea, the species has few natural predators and competitors for free space (e.g. barnacles) which likely favours the fast growth of its colonies.

A different development pattern was observed for the abundance of benthic assemblages which increased steadily over the entire immersion time reaching a maximum value on both panel surfaces after five years (Fig. 7b). This was primarily because of the growing abundance of the numerously dominant barnacle A. improvisus (up to $97 \%$ of the total macrofaunal abundance), while other taxa remained low (scyphopolyps) or even slightly decreased (mussels) in numbers with time. It has been documented in many coastal systems that the barnacles play the role of foundation species and dominate the primary substrate. The barnacles commonly appear in the mid-stage of the successional process and usually disappear at later stages (Paine \& Suchanek, 1983; Yakovis et al., 2008). An increasing number of cirripeds on the panels indicate therefore that benthic assemblages on artificial substrates are still on a successional trajectory towards the mature state. The decline or disappearance of balanids in succession sequences is often attributed to the negative effect of overgrowth by colonisers, leading to the apparent predominance of colonial taxa over solitary forms (Osman \& Whitlatch, 2004). In this study, barnacles co-existed with encrusting bryozoans and even increased in number despite the large occupancy on the panels of colonial E. crustulenta which was able to overgrow the balanid lateral walls (author's own observations). Interspecific interactions are probably weak and competitive exclusion, which has been described frequently for intertidal hard-bottom areas (e.g. Bowden et al., 2006; Pacheco et al., 2010; Wahl et al., 2011), seems to be unlikely in the southern Baltic Sea where the taxonomic richness of the resident benthic fauna is relatively low. In addition, good nutritional conditions (highly available phytoplanktonic food that is extended over time) in this eutrophic water basin and the lack of feeding interference between barnacles and bryozoans due to different feeding particle spectra (Pacheco et al., 2010) could also contribute to mechanisms underlying these patterns. Further evidence of the mid-stage succession in the benthic assemblage in terms of abundance was the notable difference to the surrounding hard-bottom communities which developed on stones at an average abundance of 157 ind. $100 \mathrm{~cm}^{-2}$ (data recalculated from Smoła, 2012). Multi-annual variations in barnacle biomass, with increasing values on both panel surfaces over most of the immersion time (Fig. 7a) also indicate the mid-successional stage of the benthic assemblages on the experimental panels.

\section{Conclusion}

Artificial hard substrates in the brackish southern Baltic Sea developed poor assemblages consisting of only five sessile taxa which all occurred in the first six months of immersion, but no clear sequence of colonising species was detected. Seasonal occupation of free space was linked with gross primary production in the water column and was driven by recruitment timing and intensity, and the individual growth rate of recruits. More diverse and numerous assemblages were observed on the panel undersurfaces presumably because of reduced physical disturbance. After three years of continuous immersion, the assemblage composition, but not its abundance, became stable and convergent towards natural surrounding communities, which is indicative of the advanced successional stage. The rate of assemblage development was relatively fast which can be attributed to weak interspecific competitive interactions and reduced feeding interference among benthic fauna.

Acknowledgements This study was supported by an internal research Grant (to A.S) from the University of Gdańsk, Poland (BW/G245-5-0239-9).

Open Access This article is distributed under the terms of the Creative Commons Attribution 4.0 International License (http:// creativecommons.org/licenses/by/4.0/), which permits unrestricted use, distribution, and reproduction in any medium, provided you give appropriate credit to the original author(s) and the source, provide a link to the Creative Commons license, and indicate if changes were made.

\section{References}

Amui-Vedel, A.-M., P. J. Hayward \& J. S. Porter, 2007. Zooid size and growth rate of the bryozoan Cryptosula pallasiana Moll in relation to temperature, in culture and in its natural environment. Journal of Experimental Marine Biology and Ecology 353: 1-12.

Andersson, M. H., M. Berggren, D. Wilhelmsson \& M. C. Ohman, 2009. Epibenthic colonization of concrete and steel 
pilings in a cold-temperate embayment: a field experiment. Helgoland Marine Research 63: 249-260.

Benedetti-Cecchi, L., 2000. Priority effects, taxonomic resolution, and the prediction of variable patterns of colonisation of algae in littoral rock pools. Oecologia 123: 265-274.

Bonsdorff, E., 2006. Zoobenthic diversity-gradients in the Baltic Sea: continuous post-glacial succession in a stressed ecosystem. Journal of Experimental Marine Biology and Ecology 330: 383-391.

Bowden, D. A., A. Clarke, L. S. Peck \& D. K. A. Barnes, 2006. Antarctic sessile marine benthos: colonisation and growth on artificial substrata over 3 years. Marine Ecology Progress Series 316: 1-16.

Bullard, S. G., R. B. Whitlatch \& R. W. Osman, 2004. Checking the landing zone: do invertebrate larvae avoid settling near superior spatial competitors? Marine Ecology Progress Series 280: 239-247.

Centurión, R. \& L. J. Gappa, 2011. Bryozoan assemblages on hard substrata: species abundance distribution and competition for space. Hydrobiologia 658: 329-341.

Clarke, K. R. \& R. M. Warwick, 2001. Change in marine communities: an approach to statistical analysis and interpretation. PRIMER-E, Plymouth. 25 pp.

Chojnacki, C.J. \& J.E. Ceronik, 1997. Artificial reefs in the Pomeranian Bay (Southern Baltic) as biofiltration sites. In: Proceedings of the 13th Symposium of the Baltic Marine Biologists: 162-172.

Connell, J. H. \& R. O. Slatyer, 1977. Mechanisms of succession in natural communities and their role in community stability and organization. American Naturalist 111: 1119-1144.

Dürr, S. \& M. Wahl, 2004. Isolated and combined impacts of blue mussels (Mytilus edulis) and barnacles (Amphibalanus improvisus) on structure and diversity of a fouling community. Journal of Experimental Marine Biology and Ecology 306: 181-195.

Dziubińska, A. \& U. Janas, 2007. Submerged objects - a nice place to live and develop. Succession of fouling communities in the Gulf of Gdańsk, Southern Baltic. Oceanological and Hydrobiological Studies 36: 65-78.

Dziubińska, A. \& A. Szaniawska, 2010. Short-term study on early succession stages of fouling communities in the coastal zone of the Puck Bay (southern Baltic Sea). Oceanological and Hydrobiological Studies 39: 3-16.

Glasby, T. M., 1999. Interactive effects of shading and proximity to the seafloor on the development of subtidal epibiotic assemblages. Marine Ecology Progress Series 190: 113-124.

Grall, J., F. Le Loch, B. Guyonnet \& P. Riera, 2006. Community structure and food web based on stable isotopes $\left(\delta^{15} \mathrm{~N}\right.$ and $\delta^{13} \mathrm{C}$ ) analysis of a North Eastern Atlantic maerl bed. Journal of Experimental Marine Biology and Ecology 338: 1-15.

Hermansen, P., P. S. Larsen \& H. U. Riisgård, 2001. Colony growth rate of encrusting marine bryozoans (Electra pilosa and Celleporella hyalina). Journal of Experimental Marine Biology and Ecology 263: 1-23.

Jansson, B.-O. \& A. M. Jansson, 2002. The Baltic Sea: reversibly unstable or irreversibly stable? In Gundersen, L. H. \& L. P. Pritchard (eds), Resilience and Behaviour of LargeScale Ecosystems. Island Press, Washington, DC: 71-108.

Kukliński, P., A. Sokołowski, M. Ziolkowska, P. Balazy, M. Novosel \& D.K.A. Barnes, 2013. Growth rate of selected sheet-encrusting bryozoan colonies along a latitudinal transect: preliminary results. In: Ernst, A., P. Schäfer \& J. Scholz (eds), Bryozoan Studies 2010, Lecture Notes in Earth System Sciences 1 (143): 149-160.

Leppäkoski, E., S. Gollasch, P. Gruszka, H. Ojaveer, S. Olenin \& V. Panov, 2002. The Baltic - a sea of invaders. Canadian Journal of Fisheries and Aquatic Sciences 59: 1175-1188.

Levinton, J. S., 1970. The paleoecological significance of opportunistic species. Lethaia 3: 60-78.

Long, M. H., J. E. Rheuban, P. Berg \& J. C. Zieman, 2012. A comparison and correction of light intensity loggers to photosynthetically active radiation sensors. Limnology and Oceanography Methods 10: 416-424.

Margalef, R., 1974. Perspectives in Ecological Theory. University of Chicago Press, Chicago. 166 pp.

Maughan, B. C., 2001. The effects of sedimentation and light on recruitment and development of a temperate, subtidal, epifaunal community. Journal of Experimental Marine Biology and Ecology 256: 59-71.

McClanahan, T. R., 1997. Primary succession of coral-reef algae: differing patterns on fished versus unfished reefs. Journal of Experimental Marine Biology and Ecology 218: 77-102.

Navarrete, S. A. \& J. C. Castilla, 1990. Barnacle walls as mediators of intertidal mussel recruitment: effects of patch size on the utilization of space. Marine Ecology Progress Series 68: 113-119.

Nikulina, E. \& P. Schäfer, 2006. Bryozoans of the Baltic Sea. Meyniana 58: 75-95.

Odum, E. P., 1969. The strategy of ecosystem development. Science 164: 262-270.

Osman, R. W. \& R. B. Whitlatch, 2004. The control of the development of a marine benthic community by predation on recruits. Journal of Experimental Marine Biology and Ecology 311: 117-145.

Osman, R. W., R. B. Whitlatch \& R. J. Malatesta, 1992. Potential role of micro-predators in determining recruitment into a marine community. Marine Ecology Progress Series 83: 35-43.

Pacheco, A. S., J. Laudien, M. Thiel, M. Oliva \& O. Heilmayer, 2010. Succession and seasonal onset of colonization in subtidal hard-bottom communities off northern Chile. Marine Ecology 32: 75-87.

Paine, R. T. \& T. H. Suchanek, 1983. Convergence of ecological process between independently evolved competitive dominants: a tunicate-mussel comparison. Evolution 37: 821-831.

Petraitis, P. S. \& E. Methratta, 2006. Using patterns of variability to test for multiple community states on rocky intertidal shores. Journal of Experimental Marine Biology and Ecology 338: 222-232.

Pickett, S. T. A., 1976. Succession: an evolutionary interpretation. The American Naturalist 110: 107-119.

Qvarfordt, S., H. Kautsky \& T. Malm, 2006. Development of fouling communities on vertical structures in the Baltic Sea. Estuarine Coastal and Shelf Science 67: 618-628.

Robins, P. E., S. P. Neill, L. Giménez, S. R. Jenkins \& S. K. Malham, 2013. Physical and biological controls on larval dispersal and connectivity in a highly energetic shelf sea. Limnology and Oceanography 58: 505-524. 
Rumohr, H., E. Bonsdorff \& T. H. Pearson, 1996. Zoobenthic succession in Baltic sedimentary habitats. Archive of Fishery and Marine Research 44: 179-214.

Seed, R. \& T. H. Suchanek, 1992. Population and community ecology of Mytilus. In Gosling, E. (ed.), The mussel Mytilus: ecology, Physiology, Genetics, and Culture. Elsevier, Amsterdam: 87-169.

Smith, S. D. \& M. J. Rule, 2002. Artificial substrata in a shallow sublittoral habitat: do they adequately represent natural habitats or the local species pool? Journal of Experimental Marine Biology and Ecology 277: 25-41.

Smoła, Z., 2012. The structure of benthic communities of the Planned Underwater Reserve Klif Orłowa. Master thesis, University of Gdańsk, Gdynia, (in Polish). 112 pp.

Sokołowski, A., M. Ziółkowska, P. Balazy, I. Plichta, P. Kukliński \& S. Mudrak-Cegiołka, 2017. Recruitment pattern of benthic fauna on artificial substrates in brackish low-diversity system (the Baltic Sea). Hydrobiologia 784: 125-141.

Sousa, W. P., 1980. The responses of a community to disturbance: the importance of successional age and species' life histories. Oecologia 45: 72-81.

Speight, M. \& P. Henderson, 2010. Marine ecology: concepts and applications. Wiley, Chichester. 276 pp.

Svane, I. \& J. K. Petersen, 2001. On the problems of epibioses, fouling and artificial reefs, a review. Marine Ecology 22: 169-188.

Todd, C. D., 1998. Larval supply and recruitment of benthic invertebrates: Do larvae always disperse as much as we believe? Hydrobiologia 376: 1-21.

Todd, C. D. \& S. J. Turner, 1986. Ecology of intertidal and sublittoral cryptic epifauna assemblages: I. Experimental rationale and the analysis of larval settlement. Journal of Experimental Marine Biology and Ecology 99: 199-231.
Tyrrell, M. C. \& J. E. Byers, 2007. Do artificial substrates favor nonindigenous fouling species over native species? Journal of Experimental Marine Biology and Ecology 342: 54-60.

Underwood, A., 1997. Experiments in ecology: their logical design and interpretation using analysis of variance. Cambridge University Press, Cambridge. 509 pp.

Valdivia, N., A. Heidemann, M. Thiel, M. Molis \& M. Wahl, 2005. Effects of disturbance on the diversity of hard-bottom macrobenthic communities on the coast of Chile. Marine Ecology Progress Series 299: 45-54.

Wahl, M., H. Link, N. Alexandridis, J. C. Thomason, M. Cifuentes, M. J. Costello, B. A. P. da Gama, K. Hillock, A. J. Hobday, M. J. Kaufmann, S. Keller, P. Kraufvelin, L. Krüger, L. Lauterbach, B. L. Antunes, M. Molis, M. Nakaoka, J. Nyström, Z. ban Radzi, B. Stockhausen, M. Thiel, T. Vance, A. Weseloh, M. Whittle, L. Wiesmann, L. Wunderer, T. Yamakita \& M. Lenz, 2011. Re-structuring of marine communities exposed to environmental change: a global study on the interactive effects of species and functional richness. PLoS ONE 6(5): e19514.

Wołowicz, M., A. Sokołowski \& R. Lasota, 2006. Effect of eutrophication on the distribution and ecophysiology of the mussel Mytilus trossulus (Bivalvia) in southern Baltic Sea (the Gulf of Gdańsk). Limnology and Oceanography 51: 580-590.

Wootton, J. T., 1994. Predicting direct and indirect effects: an integrated approach using experiments and path analysis. Ecology 75: 151-165.

Yakovis, L. E., A. V. Artemieva, N. N. Shunatova \& M. A. Varfolomeeva, 2008. Multiple foundation species shape benthic habitat islands. Oecologia 155: 785-795. 